\title{
Islamic Tourism: The Characteristics, Concept and Principles
}

\section{Dr. Amini Amir Abdullah, Dr. Mohd Daud Awang, and Dr. Norsazali Abdullah}

\section{Abstract}

The Islamic economic sector has grown rapidly in Malaysia and Islamic businesses can be found in a wide range of sectors including culinary, Islamic finance, Islamic takaful (insurance and mortgage) industries, fashion, cosmetics, pharmaceuticals, entertainment, and tourism industries. Islamic tourism, in particular, offers a new means of developing the tourism industry in Malaysia whilst maintaining the ethics, culture and values of Islam. Islamic tourism is not defined as a visit to the mosque alone, but the visit is closely related to nature, culture, or creativity that integrates with Islamic values. Currently, the concept of adherence to Islam (which has been called as Shariahcompliant) has gained traction across the globe. In response to this new lifestyle trend, many countries (including those such as Korea, Japan, Australia, Thailand, and New

Corresponding Author: Dr. Amini Amir Abdullah amini@upm.edu.my

Received: 2 May 2020 Accepted: 4 July 2020 Published: 14 July 2020

Publishing services provided by Knowledge E

(c) Dr. Amini Amir Abdullah et al. This article is distributed under the terms of the Creative Commons Attribution License, which permits unrestricted use and redistribution provided that the original author and source are credited.

Selection and Peer-review under the responsibility of the ICIEHI Conference Committee. Zealand which do not have a domestic Muslim majority) are beginning to introduce tourism products related to the halal concept or Islamic orientation. The definition of Islamic tourism is still unclear and encompasses various terms such as Halal Tourism, Halal Friendly Travel Destinations, Halal Travel, Islamic Travel Destinations, and Halal Lifestyle. Even in Malaysia, a leader in this sector, the concept of Islamic tourism is still liminal. However it offers huge potential, both for the country's tourism sector and the country's Islamic population, contributing to the preservation and appreciation of Islamic culture in Malaysia. Islamic tourism is not only related to religious values but also must be in line with every way of life that is not contrary to Islam. Not many companies and agencies organize halal tourism packages because they think it is not a necessity and a profit. Many companies are more focused on routine Islamic tourism such as Umrah and Hajj. This paper considers in detail the characteristics, concept and principles of Islamic tourism.

\section{Introduction}

The recent Islamic-based economic sector has increased steadily, i.e. culinary, Islamic finance, Islamic takaful industry (insurance and mortgage), fashion, cosmetics, pharmacy, entertainment, and tourism. Islamic tourism is seen as a new way to develop Malaysia tourism industry that upholds Islamic ethics, culture and values. Islamic tourism is not defined as a tour to the pilgrimage or to the mosque per se, but the tour comes from nature, culture, or creativity with Islamic values. 
Currently the concept of Islam (what has been termed as Shariah-compliant) has become a trend in the global economy, ranging from food and beverage products, finances to lifestyle. As a new trend of lifestyle, many countries are starting to introduce tourism products with the concept of halal or Islamic orientation. Even countries like Korea, Japan, Australia, Thailand, New Zealand, and so on which not a predominantly Muslim country have aided in developing Islamic tourism prospects and products.

The terminology of Islamic tourism still does not have clear boundaries and still using various terminologies such as Halal Tourism, Halal Friendly Tourism Destination, Halal Travel, Muslim-Friendly Travel Destinations, Halal lifestyle, and more. Even in Malaysia itself the concept of Islamic tourism is also not clear. According to some experts of Islamic tourism, tourism is a complementary product and does not eliminate the conventional types of tourism. As a new way to develop Malaysian own Islamic tourism, upholding Islamic culture and values, efforts should be made to enhance Islamic tourism without eliminating the uniqueness and originality of Malaysian culture.

Islamic tourism is not only related to religious values but comprehending every walk of life that is not contradicting to Islam. The condition of Islamic tourism in Malaysia is still not maximized, whereas if we worked more seriously, the potential of Islamic tourism in Malaysia is very large. Not many companies and agencies organize trips that packs an inbound trip with a halal travel package. Many companies are more focusing on outbound travel such as 'Umrah and Hajj. In terms of history, Aminah, the mother of Prophet Muhammad SAW. one day intended to go to Yathrib to visit her husband's grave. For this she went out of Makkah, across five hundred kilometers to the destination with her child; Umm Aiman accompanied by her father-in-law Abdul Mutalib, where she lived for one month, after which she returned back, during her journey she had facing illness ending with the last breath and rest in peace in the place of "Al-Abwa" which lies between Makkah and Medina (Al-Mubarakpuri, 2000).

\subsection{The Definition of Islamic Tourism}

There are many terms manifesting the meaning of Islamic tourism such as Syariah tourism, halal tourism, halal travel, or Moslem friendly destination. Islamic tourism is an activity supported by various facilities and services provided by the community, entrepreneurs, government, and local governments that comply with the requirements of Islam and Syariah. The term of Islamic tourism is used by many people because the characteristics of its products and services are universal including tourist services, foods and drinks, attractions, and tourist destination in general as long as it does not conflict 
with the values and ethics of Syariah. So, Islamic tourism is not limited to religious tourism only (Duman, 2011. Carboni et al., 2014. Battour and Ismail, 2015).

Based on the above understanding, the concept of Islamic tourism supposedly is not contrary to the values and ethics of Islam and closely related to the concept of halal and haram in Islam. Halal means justified, while haram is defined as prohibited. The concept of halal can be viewed from religious and industry perspectives. What is meant by religious perspective is what is allowed to be consumed by Muslim consumers according to Islamic belief and teachings. It brings consequence of consumer protection. While from industry perspective, for food producers, this halal concept can be interpreted as a business opportunity. For food industries, that targeted Muslim consumers, it takes a guarantee of halal product will increase its value in the form of intangible value. For example, food product with halal packaging and labeling is more attractive to Muslim consumers as compared to others.

Tourism has various social and cultural impacts. Halal tourism is a new product of Muslim and non-Muslim markets. Halal market is classified into three categories i.e. food, lifestyle (cosmetics, textiles, etc.), and services (tour packages, finance, transportation). Therefore, Islamic tourism can be defined as tourism and hospitality created by consumers and producers in accordance with the teachings of Islam. Many countries in the Islamic world are taking advantage of increased demand for Muslim friendly tourist services.

Islamic tourism is a new concept of tourism. It is not religious tourism per se like performing 'Umrah or Hajj. Islamic tourism is a tourism activities that caters holidays with customize holiday style according to the customer needs and demand. In this case, the hotel that carries the principles of Shariah does not serves alcoholic drinks and has a separate swimming pool and spa facilities for men and women.

\subsection{The Philosophical Framework Of Islamic Tourism}

Islamic tourism is a pleasurable activity or activity that can reestablish health, comfort, calm and feeling. Islamic tourism can also bring a person to forget about the sadness and strengthening the will by obeying Islamic rules and discipline. In this case, Islam is not a jumble or stiff religion, but is very flexible in adjusting the truth and the value of a good life. Allah says: "But how can you disbelieve while it is you to whom the communications of Allah are recited, and among you is His Messenger? And whoever holds fast to Allah, he indeed is guided to the right path" (Surah Ali 'Imran: 101). 
Allah says in this verse that whoever holds fast to Allah, he indeed is guided to the right path of Allah pleasure. Allah also says: "(This is) the truth from your Lord, so be not of the disputers" (Surah Ali "Imran, 60). This verse emphasizes that the truth comes from Allah, so do not be doubtful. In Surah Yusuf, verse 3, Allah says: "We narrate to you the best of narratives, by Our revealing to you this Quran, though before this you were certainly one of those who did not know". Apart from reading the Quran and remembrance (zikr), activities that allow someone to relax and get rid of stress are like resting, taking a tour and traveling. Allah says: "Say: Travel in the land, then see what was the end of the rejecters. Say: To whom belongs what is in the heavens and the earth? Say: To Allah; He has ordained mercy on Himself; most certainly He will gather you on the resurrection day- there is no doubt about it. (As for) those who have lost their souls, they will not believe" (Surah Al-An'am, 11-12). (See also Surah Ali 'Imran: 137, Surah Nuh: 36, Surah Al-Naml: 69 and Surah Al-Rum: 42)

Allah emphasizes in this verse that mankind should go on the earth and then see how the end of people who deny Allah. In this verse, Allah SWT. asserts that what is in heaven and this world belongs to Allah SWT. alone i.e. one of the Islamic tourism activities is to take lessons from the effects of the abandonment of the people who were cruel and disobedient to Allah SWT. Muslims are encouraged to travel to see the greatness of Allah's creation, to strengthen mental health and spiritual significance and to appreciate the creations of Allah SWT. Historically, the adventure to Mecca is regarded as a pilgrimage and 'umrah. Islamic tourism activities can refresh mind, bring peace, give knowledge, restore and refresh eyes like sightseeing green gardens and parks, visiting historic sites and participating in Islamic tourism activities in general.

RasulAllah SAW. says which means: "Three things that can please the sights: See the green thing, look at the flowing water and look at the good face. Retain and refresh body health through body movements such as taking a tour, recreation and leisure. In a hadith, it was described that the Prophet Muhammad SAW. advices Abdullah bin Amr bin Al-As: "O Abdullah bin Amr! Surely you have the right to Allah and your right to your body, and upon you the right to your family. So give the rights to those who have the right”.

\subsection{Islamic Tourism and The Tauhidic Philosophy}

The Malaysian government efforts in the aspects of Islamic tourism development are in line with the philosophy and principles of Islam. It aims to protect injustice in the 
acquisition, service and use of natural resources, by fulfilling human satisfaction to support the responsibility towards Allah and the whole community.

Human needs and spirituality must be fulfilled in an integrated form. This approach provides a central place for the integration of ethical and moral values in all human needs, activities and behaviors including in Islamic tourism activities. The philosophy of Tauhid advocates unity in knowledge to educate people for the happiness of life (Al-Sa'adah), well being and the pleasure of Allah (Rida Allah) and related associations as a role that ultimately supports the dignity and glory of Islam.

The convergence of Islamic tourism development is integrated and comprehensive with emphasis given on the spiritual dimensions besides not avoiding the material dimensions. The appreciation of Islamic morals (akhlaq) must be included in all Islamic tourism affairs and operations. The tauhid philosophy also teaches the effort to establish the attitude of obeying the command of Allah and to avoid its prohibitions. In this principle there is also the value of doing justice, making good, helping one another, taking warning and avoiding injustice. This is in accordance with Allah SWT. word: "Surely Allah enjoins the doing of justice and the doing of good (to others) and the giving to the kindred, and He forbids indecency and evil and rebellion; He admonishes you that you may be mindful" (Surah al-Nahl: 90).

Tauhid also educates people to be sensitive in their relationship with the creation of Allah SWT. the use of natural resources as efficiently as possible, do not waste and take into account the consequences of the use of these resources so that virtue and justice are preserved. Therefore, in Islamic tourism intention for tourism activities is for the sake of Allah. There should be no element that conflicts with the creeds like shirk, kufr and nifaq. Any Islamic activities should not contradictory to Islamic law. Covering the 'awrah is as important as the objective of Islam itself. Ethics and moral of Islam should be preserved and there should be no element of contradiction to the commandments of Allah, or against the prohibitions, or containing gambling or betting or wasting elements as well as no harmful elements.

\subsection{The Characteristics of Islamic Tourism}

The definition of Islamic tourism is more extensive than religious tourism. It is a tour based on Islamic Syariah and values. Consumers of Islamic tourism are not only Muslims but also Non-Muslims who want to enjoy local wisdom. The general criteria for Islamic tourism are:

i. Orientation of common good. 
ii. Enlightenment and orientation of tranquility.

iii. Avoiding idolatry and superstitious elements (khurafat).

iv. Free from immorality.

v. Maintain security and comfort.

vi. Keep environmental sustainability.

vii. Prioritizing the more important fundamentals

viii. Respect for social and cultural values and local wisdom.

\section{i. Orientation of common good.}

Islam in the sight of Allah is a sincere surrender to Allah in all matters until it is said, even if a person claims to embrace Islam, if he does not surrender vigorously to Allah with the real meaning, he is not yet a true Muslim because he has not given up (HAMKA, 1980). So, a Muslim is a submissive Muslim and surrenders to Allah totally and earnestly without any excuse. The man who fulfilled all the commandments of Allah and abandoned all His prohibitions, then he was said to be a true Muslim. This is also applied in Islamic tourism.

Islam is revealed by Allah SWT. to Prophet Muhammad SAW. of course, cannot be confused with the definition of religious terms in general, which are in the form of a general teaching that expresses the relationship between man and the supernatural power or a mere or ritualistic elements. Islam as Al-Din covers all the fields of human life. Islamic teachings contain the aspects of faith, practice and laws relating to the spiritual and the physical and all matters of life in the world and the Hereafter for the well-being of human life. Islam as AI-Din has governed the spiritual relations between man and God, social and spiritual relations between human beings, human relationships with human beings and human relationships with the environment. This is a wider sense than the meaning "religion" terminology.

The definition of Islam as a unique and dynamic "religion" is the best definition for religion in general. Syed Muhammad Naquib al-Attas (1985: 3) explains: "The very name of the religion: Islam, is in reality the definition of religion: submission to God. But the fundamental element in man's act of submission to God is his sense of indebtness to God for giving him existence, so that this sense of indebtness is a prior condition to true submission".

The meaning of this statement explains that the true meaning of religion is Islam itself which is in fact a true definition of religion of self-surrender to God. But the fundamental 
element in human self-surrender to God is the sense of human indulgence to God for granting its existence. Thus, the sense of indebtedness is a prime requirement for actual submission. Islam is called al-Islam due to the obedience and obedience of obedience to God's command and abstaining from His prohibited forbearance, commendation or fabrication (Al-Maududi, 1989). The obedience and adherence to al-Amr (commandmend) and al-Nahy (prohibition) are not fabricated but based on the willingness, sincerity and submission to achieve the true nature of Allah's will (the pleasure of Allah).

When we travel internationally, we have the opportunity to know more about tourism attractions, culture and heritage destinations. Our country also is rich in various natural beauty and treasures. People say, "Far traveling, wide-sighted" which means when we are wandering more and more, the more experience and knowledge we gain. Therefore, there are people who love to travel abroad to see the culture and life styles of other countries. Traveling is a fun activity. In addition to excitement while traveling, we can also develop our country's tourism industry. Indirectly, we can help to advance our country when traveling domestically. Traveling within the country will increase the spirit of love for the country. This happens because by visiting historical places, one will be able to see, understand, and appreciate how the previous generation builds and defends the country. Traveling also can deepen our knowledge of the affairs of our country and others, assist the development of the local tourism industry, save money on expenses, reduce the outflow of our currency, enhance the love of the country, and more secure traveling in our own country. Changing trends in domestic travel to overseas has increased since the availability of low-cost airlines that anyone can afford. In fact, the return ticket on air travel prices offered for international destinations are not just the same as destinations within Malaysia but are getting cheaper.

\section{ii. Enlightenment and orientation of tranquility.}

This feature reflects Islamic tourism as a tourism activity that has the cheerfulness, freshness and serenity of the chalet, homestay and hotel areas, with no noise and is perfect for those seeking peace outside of the busyness of the city. Travelers like to enjoy tranquility, sightseeing and enjoy the beauty of nature created by Allah SWT.

The believers obtain the protection of Allah from the threats of enemies (Surah AlHaj: 38), the happiness of the world and the Hereafter (Surah Al-Nahl: 97), liberating the mind from stagnation, gain salvation, the harmony, the peace and the guidance of Allah (Surah Al -Baqarah: 15). People who read, appreciate and practice the Qur'an have the peace of mind. The believers calming their hearts with "zikrullah" are the lucky 
ones. With "zikrullah", it can make calm the hearts of sincere human beings and seek the pleasure of Allah SWT. Allah SWT. said in Surah AI-Ra'd verses 28-29: which mean: "Those who believe and have peace in their hearts with zikrullah". With "zikrullah" and quran recitation, mankind will find peace and calmness. Those who believe and do good deeds, have the exquisite bliss and the best place to return.

\section{iii. Avoiding idolatry and superstitious elements (khurafat).}

Some Islamic societies live in apostasy and superstitious when visiting idols, monuments related to other religions, other religious attractions as it provides benefits to other religions other than Islam and contradicted to Islamic faith. Muslims should visit mosques, Islamic monuments, Islamic historical sites and Islamic attractions. Shirk, superstitious and credulous elements can eliminate pure Islamic identity which is the core of civilization. Superstition, shirk and fallacy related to the devastation of Islamic faith are forbidden because of lies in the name tourism especially if the superstition is related to detruction to the belief of Allah. The dangers are more severe and the threats are huge.

Thus, with the sources of the Qur'an and al-Sunnah, ijtihad, Qias and al-Maslahah, Islamic tourism develops with its own style and always influence the minds of Muslims. The question of Islamic tourism needs to be seen in the context of the perspectives of ljtihadiyyah, Fiqhiyyah, Usul al-Fiqh and contextual problems. In the days of Tabi'in and Tabi' al-Tabi'in, the pattern of Islamic thoughts began to expand rapidly with the objective of strengthening the faith, abolishing superstition and heresy, purifying the teachings of Islam and allowing Islam to be practiced in total. These efforts have changed its paradigm shift in the wake of the challenges of Western colonization around the 18th, 19th and 20th centuries.

\section{iv. Free from immorality.}

The convergence of knowledge as the core of strength can be seen in the three main strategies for creating first-class human capital that combines knowledge, science and technology, research and development, innovation and high moral strength. Interests and habits of visiting places of immorality, immoral and unprofitable places negatively affect the development of human mind and physical. For example visiting nude beach, night club, pub, discotheque and others. So, too passionate pursuing the enjoyment of 
the world can cause forgetfulness and be trapped by adultery and prostitution. This is contrary to the characteristics of Islamic tourism.

\section{v. Maintain security and comfort.}

Islamic tourism is also concerned with wellness, security, comfort and safety. All tourism industry operators are obliged to hold and maintain their respective places, safe and non-hazardous workplace systems at work. This will contribute to the security and safety of tourists. They also need to increase the level of safety and comfort of tourists. Malaysia is increasingly aware of the need to create comfort throughout the journey for international travelers through travel agencies. Proactive and effective efforts should be taken by all parties to restore the confidence of the international community to the level of safety and comfort of tourists in our country.

Travel services must be upgraded to ensure the convenience and comfort of tourists. Similarly, infrastructure and infostructure facilities should be upgraded. The main factor of tourist arrivals to a country is because of infrastructure facilities such as communication, transportation and transportation. This is because the tourists need coziness, well being, comfort, safety, and peace of mind.

\section{vi. Keep environmental sustainability.}

The term sustainability may be so synonymous with our society today. However, how much do our societies understand the concept of sustainability in the true sense especially in translating the concept of protection and conservation of the environment in Islamic tourism? What is our attitude towards environmental perotection and preservation? Environmental care is the responsibility of all. A responsible government should consider policy and legislation to ensure environmental issues such as haze, open burning, river pollution and others be well and comprehensively addressed.

The real concept of environmental sustainability is to ensure that the environment is well protected and that all the components in it are unchanged or preserved as it were. The environment is not just managing solid waste, controlling pollution and maintaining cleanliness of public areas but there should be a well planned environmental protection and preservation programs. This is the foundation of life and needs to be implemented as the duty and importance of the well-being of society. The way to preserve nature starts with the small things in the community and then to the top leaders of the country. This mind is driven by the awareness of how important it is to channel knowledge about 
sustainability and to understand and appreciate nature in harmony with the application of life-inspired environmental suatainability.

\section{vii. Prioritizing the more important fundamentals}

Muslims often misunderstood the importance of Islamic tourism in their lives in the world. In dealing with Islamic tourism development affairs, Muslims often place themselves in a complicated situation - between worldly importance and demands of the hereafter. Which is more important, life in the world or life in the hereafter? There are a lot of confusion. We do not deny that as Muslims, we hold on to the philosophy that life in this world is temporary and our goal is to live a better and lasting life. In Islamic tourism, we cannot disregard the demands of Fardu Al-'Ain such as prayer, fasting, respect and devotion to parents or to abandon the command of Allah SWT. These elements should be a priority as compared to other means.

\section{viii. Respect for social and cultural values and local wisdom.}

Islamic value system provides a framework for analyzing the norms of society, excellence, trust, and behavior. The value becomes a measure on goodness and happiness. Islam becomes a soul in the whole of the social and cultural system of the Malays.

The value of respecting others is often associated with the Islamic value system. Culture is a process of implementing cultural and religious values. The values of Islam have shaped social rules that construct social discipline and establishing an effective social relationship. It is therefore important for us to appreciate the value of this distinction and to respect such diversity. This will help us to enjoy a harmonious life. Respecting cultural and religious diversity is also important.

We feel lucky to be born in a multiracial country. Malaysians have been educated with noble values of acceptance by respecting the differences in their ethnic cultures. Individual development through the practice of noble values will lead to national development as the way of life of the society reflects the identity of a nation that is progressive, kind, caring, respectful, wise and of good values. The experience of staying homestay in a traditional village setting may be the most effective way for foreign tourists to enjoy the real atmosphere of the village life and get to know Malaysia more closely. Figure 1 summarizes the characteristics of Islamic tourism. 


\section{The Characteristics of Islamic Tourism}

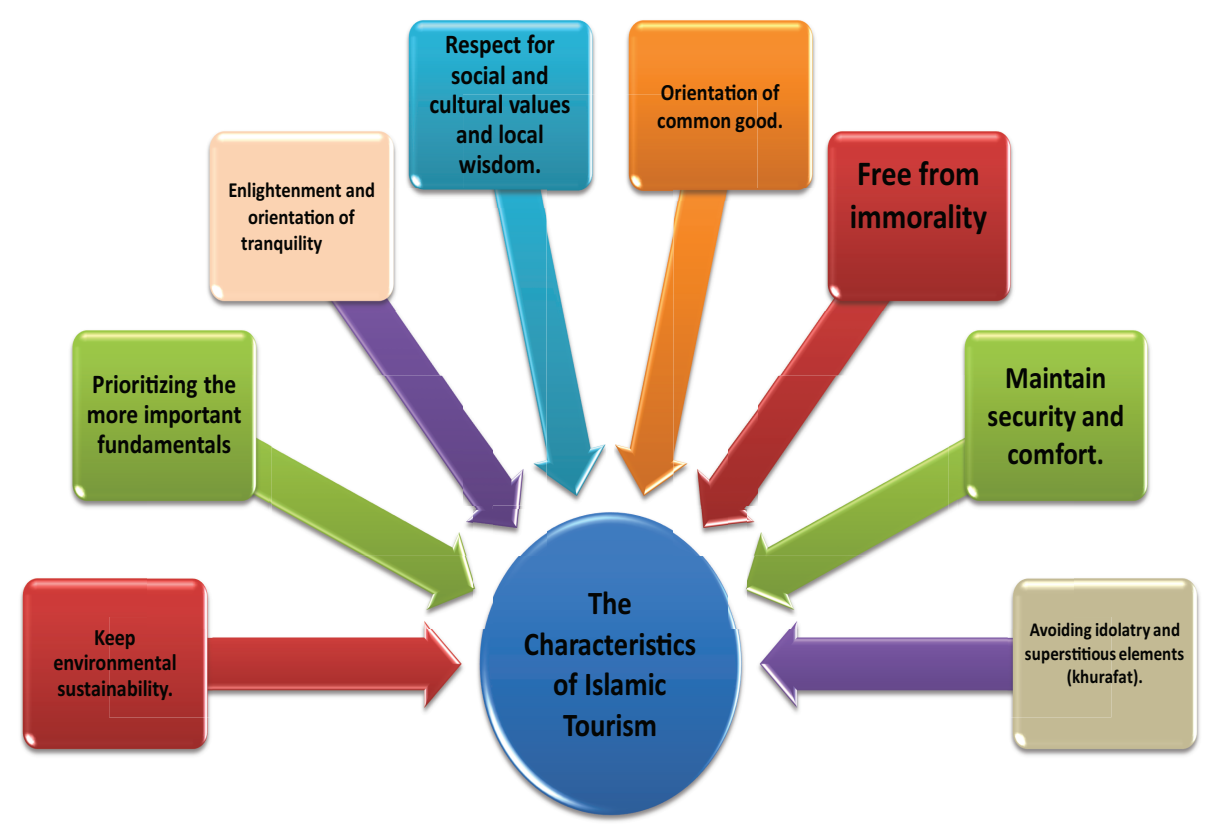

Figure 1: The Characteristics of Islamic Tourism.

\section{The Concept of Islamic Tourism}

The first concept of Islamic tourism is the rububiyyah concept that emphasizes the nature of Allah SWT. as the Ruler who makes rules and guidance aimed at keeping and fulfilling the needs of the living beings for the sake of happiness in the world and the Hereafter. As the Creator of this universe, only Allah s.w.t. alone who understands the journey and the best substance for his nature and creatures. Hence the rules and systems that come from revelation are for the sake of harmony, justice, preservation and the well-being of human life.

All activities in the world need to be viewed in terms of present value for the end of the Day. Since life in this world is an attempt to test anyone who best practices, whether religious or worldly practice and all the gifts available to mankind are in the form of trust, human beings are responsible to Allah and the success of the Hereafter will depend on his world's performance. This is because in this world activity in Islamic tourism is one of its elements. So the question of trust and accountability cannot be avoided from being accountable on some else during the Last Day. Human being as the Caliph of Allah is a trustee who manifests the understanding in managing, administering and prospering 
the world that is still uninterrupted from the relationship with the elements of Tauhid and Rububiyyah.

The relationship between human beings is fundamental and one element of Islamic brotherhood. It will drive to noble values and universal security. This world belongs to Allah. The property owned by man is not absolute, it is even a test and trust of Allah. The awareness of property ownership should be in accordance with Shariah and will make man manage his ownership as directed by Allah SWT.

Allah explains in the Qur'an that Allah permits mankind with all the available transportations to move and walk either on land or sea. Everything is valid and permissible with the permission of Allah. Allah says: "He it is Who makes you travel by land and sea; until when you are in the ships, and they sail on with them in a pleasant breeze, and they rejoice, a violent wind overtakes them and the billows surge in on them from all sides, and they become certain that they are encompassed about, they pray to Allah, being sincere to Him in obedience: If Thou dost deliver us from this, we will most certainly be of the grateful ones" (Surah Yunus: 22).

Allah encourages mankind to walk in His earth and to see how Allah SWT. has begun the creation of beings from its origin; then Allah will begin the creation again (in the Hereafter) in the form of a new event. Allah has power over all things. Allah said: "Say: Travel in the earth and see how He makes the first creation, then Allah creates the latter creation; surely Allah has power over all things" (Surah Al-Ankabut: 20). This verse motivates mankind to travel in the earth to observe the uniqueness and speciality of Allah's creations.

\section{The Principles of Islamic Tourism}

The principles of Islamic tourism are as follows:

\section{i. Intention}

As a true Muslim, one needs to have the right intention (niyyah). Are you truly having a tour just for the sake of worldly affairs, personal gain or prestige or just for the sake of leisure and pleasure? There are so many other opportunities in tourism to do good work for the cause of Allah.

The Prophet Muhammad SAW. said: "Actions are (judged) by motives (niyyah), so each man will have what he intended. Thus, he whose migration (hijrah) was to Allah and His Messenger, his migration is to Allah and His Messenger; but he whose migration 
was for some worldly thing he might gain, or for a wife he might marry, his migration is to that for which he migrated" (Jamal Ahmed Badi, 2002).

One of basic Islamic legal maxims is AI-Umur bi maqasidiha (Every matter is evaluated based on the intentions and goals). This method emphasizes that every matter and action is considered based on the intention and purpose. The main basis of the construction of this first method is developed from the hadith of 'Umar al-Khattab: "Surely every practice is considered with intent and indeed for every person what intended" (Narrated by Muslim).

In Allah's sight, intention has a great impact. In fact, anyone who has the intention to do good and welfare but failed to do so because there are difficulties (masyaqqah), he will be given a reward by Allah.

\section{ii. The Principles of Taklifiyyah}

In Islam, there are five elements of Taklifiyyah (Liability) or Al-Ahkam Al-Taklifiyyah i.e.:
a. Wajib (obligatory)
b. Mandub (encouraged)
c. Haram (impermissible)
d. Makruh (hated)
e. Mubah (neutrality)

\section{a. Wajib (obligatory)}

Obligatory means any injunction or regulation made by Allah SWT. based on ordinary stand e.g. five times prayer or fasting in the month of Ramadan. Anything that is an obligation is a must to be practiced and will be rewarded by Allah and whosoever ignores the obligation will be punished.

\section{b. Mandub (encouraged)}

Mandub means any injunction or regulation made by Allah SWT. which is not based on ordinary stand e.g. rawatib prayer or Duha prayer. It is encouraged to be practiced and will be rewarded by Allah and whosoever ignores the mandub will not be punished. 


\section{c. Haram (impermissible)}

Haram means anything that is prohibited by any injunction or regulation made by Allah SWT. based on ordinary stand to avoid it e.g. consuming usury (riba) or not respecting parent. Anything that is impermissible must be avoided and will be rewarded by Allah (because of sincerity) and whosoever practices the impermissible will be punished.

\section{d. Makruh (hated)}

Makruh means anything that is prohibited by any injunction or regulation made by Allah SWT. which is not based on ordinary stand to avoid it e.g. holding penis with right hand while pissing. Anything that is makruh must be avoided and will be rewarded by Allah (because of sincerity) and whosoever practices the makruh elements will not be punished.

\section{e. Mubah (neutrality)}

Mubah means anything that is not related to any injunction or regulation originally e.g. eating at night during Ramadan.

\section{iii. For the sake of 'Ibadah (Worship)}

This principle covers all involvement in Islamic tourism activities which can be considered as worship. Every engagement would be rewarded by Allah with due consideration. By Islamic tourism is one of its mechanisms. Riba is out of this principle because it is obtained without effort. It is not permissible to go on Islamic tourism with debts. Allah says: "And to Thamood (We sent) their brother Salih. He said: O my people! serve Allah, you have no god other than $\mathrm{He}$; He brought you into being from the earth, and made you dwell in it, therefore ask forgiveness of Him, then turn to Him; surely my Lord is Nigh, Answering" (Surah Hud: 61).

Allah says in this verse that He (Allah) has made mankind of the earthly things and wants mankind to prosper and mobilize the earth. Man as the vicegerent of Allah has a role to manage, operate, maintain, prosper and benefit the nature for the purpose of worship of Allah. An important concept in Islamic tourism is that it is beyond the concept of business interests and making profit alone, but more focused on getting the pleasure of Allah and the reward of worship. 
In terms of worship, no one can perform worship unless proven it has been determined by the Shari'ah as worship. Thus, in search of a halal of Islamic tourism, is to look good in the product and to determine whether there is evidence of the banning of the product. If nothing banned it, then the ruling is permissible or halal although there is no evidence of justifying it.

\section{iv. To obtain the pleasure of Allah (Mardatillah)}

Muslim traders are exploring to the end of Asia with muballigh and da'i (preachers), Sufi members and tariqah (Sufism orders) and scholars. It should be remembered that Islamic traders are not the only ones who have come only because of their trade missions or adventures (as most orientalists explain) even their arrival is due to the consciousness of upholding the religion of Allah in this land and attaining mathatah (the pleasure of Allah). Islam grows not because of economic activity but because of its economic actors who are aware that he is also a preacher, Islam is also "taken" with merchandise. The strength of Islam is stronger when the Turks convert to Islam and this widened the existing Islamic empire. Obligation to study the science demanded by the Qur'an, the advice of the Prophet Muhammad s.a.w. so that the quest for knowledge is derived from "cradle to the grave" to provide motivation, inspiration and intensive effort in the excavation of knowledge.

\section{v. The Principal of Hajiyyah and Tahsiniyyah}

Imam Al-Ghazali Rahimahullah has formulated and elaborated the theory of Maqasid Al-Shariah, and has categorized it into three maslahah requirements i.e. daruriyyah, hajiyyah and tahsiniyyah (Chapra, 2008, Kamali, 2007). Daruriyyah is a need and a must for the society whereas without the elements under the category of daruriyyah, the system of the country will experience chaos. Daruriyyah is a general interest (maslahah) and basis involving the maintenance of five matters i.e. religion, life, mind, ancestry and wealth. All these elements can be regarded as indefinable and necessary needs. If one of these needs is not fulfilled, human life will no longer meaningful. Any actions that violate these five things will be considered as mafsadah (destructive). The need for hajiyyah is the elements that facilitate human life. On the other hand, the needs for tahsiniyyah are matters related to dignity, manners, behavior, morals and ethics that lead to the perfection of life. Al-Ghazali further refines the requirement into conservation five 
essential elements (known as Al-Dharuriyyat Al-Khams) namely the religion (Ad-Din), the life (An-Nafs), intellect (Al-'Aql), descent (Al-Nasl) and wealth (Al-Mal).

Under the principle of Hajiyyah - human interest and needs are fulfilled in order to create ease and spaciousness in performing tasks in life and at the same time avoiding hardships and difficulties. Although it does not come to a level of basic needs that can lead to the destruction of life of human beings, it is necessary to avoid the hardships of life or destruction to the society. This absence of this mas/ahah (hajiyyah) will not affect life totally but will cause a little bit of trouble.

Tahsiniyyah - this kind of maslahah is needed as a perfection for keeping the honour of human life that involves glory, good morals and customs and leaving bad attitude, moral and ethics. All these are required to guarantee the smoothness of human life in society. The absence of it is not giving great implications to human life but it is still important.

Therefore, Islamic tourism must be in line with the Shariah goals of protecting and preserving religion (hifz ad-din), safeguarding life (hifz an-nafs), preserving and protection of intellect (hifz al-'Aql), protection of (hifz Al-Nasl) and safeguarding the property (hifz al-Mal). Every activity of Islamic tourism must not be contrary to the principle of protecting or preserving the interests of reason, religion, property, life and nasab or descendants of mankind.

\section{vi. The principle of Istikhlaf (Mankind as the vicegerent of Allah on the earth)}

Humans are the caliphs of Allah on this earth and trustees to prosper the world. Everything in this world is the absolute property of Allah and created for human needs. Man is responsible to Allah for everything that is being worked on and owned. This principle outlines the ownership of the property and the way it is spent shall be in the manner and method of Allah's favour. The use of property must be for the survival, the welfare of the owner and his/her family and society. It also involves the flow and spending of money in any economic area.

\section{vii. Limited Freedom and According to Moral Values (Akhlaq)}

Islam gives freedom to take a tour and doing recreational activities within the scope of the definition of Islamic tourism. However, moral values and good qualities of virtues are the basis of filling the principle of freedom. All conventional tourism practices that 
are contrary to Shariah are considered to be misusing the sense of freedom. Therefore, Islamic tourism practices cannot violate the rules and teachings of Islam. Allah says: "O you who believe! when the call is made for prayer on Friday, then hasten to the remembrance of Allah and leave off trading; that is better for you, if you know. But when the prayer is ended, then disperse abroad in the land and seek of Allah's grace, and remember Allah much, that you may be successful” (Surah Al-Jumu'ah: 9-10).

This verse emphasizes the call of Allah SWT. to believers to make a balance between obligations in worship and work. When the azan (call for prayer) sounds to perform the prayers then immediately discharge it and abandon all the activities of the world. The Muslims who have finished performing the prayers are commanded by Allah SWT. to work and to obtain His bounties. That gifts can be in the form of property, health, knowledge, peace and prosperity. Muslims are always encouraged to remember Allah SWT. anywhere, anytime and in any situation to always performing zikrullah (rememberance of Allah). If they can do that then they will have the luck of happiness and peace of life.

\section{viii. The Principle of Social Justice}

This principle is a dynamic foundation for organizing and implementing economic affairs (and part of it is Islamic tourism) in a society. The excellence of the Islamic tourism system requires planning, arranging, implementing, monitoring, continuous improvement of Islamic tourism systems based on the spirit of justice and transparency. This spirit provides space for all individuals to involve directly or indirectly to function positively and optimistically.

The management of Islamic tourism and its mechanism of actions must be directed towards the achievement of economic justice. A country should be able to provide individual fundamental needs through the following actions:

a. Maintaining religious appreciation through the application and implementation of religious values in all matters.

b. Improving the community thinking power and the quality of knowledge.

c. Providing freedom and legal guarantees to the public to voice out their opinions in accordance with the principles of shura relating to tourism affairs.

d. Guarantees in determining the freedom of cooperation between the private and the government, within or outside the country in order to activate capital and create Islamic tourism activities and opportunities.

e. Build a solid civilization so that future generations will continue to be excellence. 


\section{ix. Permissible Means}

The ways to obtain financial support and expanses for Islamic tourism activities must be through a halal way (not by doing riba practices, fraud, oppression, bribery, exploitation and other means which are contrary to Islam). Travel activities must not involve tyranny, oppression, wastage, endangering lives or other people's lives and damaging the environment.

\section{$x$. The Intervention of the Government}

Syariah Islamiah requires the concept of intervention of the government in Islamic tourism and economic activities, whether in the form of management, preparation, distribution, monitoring and planning. With the political power in the hands of the government, it has the right to intervene in Islamic tourism affairs to protect and secure social stability and justice, provided it must be Shariah-compliant. The government that is entrusted by the people are responsible for maintaining public order specifically to uphold the divine justice.

\section{xi. The Principles of Removing Destructive Manners}

Islam prohibits all forms of moral decadency, social problems, personal damage, community damages, family and country destruction. In addition, environmental damage also to be avoided in all Islamic tourism activities. Therefore, Islam prohibits elements such as oppression, fraud, theft, pollution, wastage and so on in the Islamic tourism system.

\section{xii. Promoting Quality of Life and Improvement}

Islam teaches that in doing worship and way towards the Hereafter, this world should not be neglected. The world becomes a farm or bridge, while the ultimate goal of all human activities is to the glory and happiness of the world and Hereafter. Allah says: "And seek by means of what Allah has given you the future abode, and do not neglect your portion of this world, and do good (to others) as Allah has done good to you, and do not seek to make mischief in the land, surely Allah does not love the mischief-makers" [Surah Al-Qasas: 77]. 
In this verse, Allah asked mankind to seek what He has bestowed upon mankind in the Hereafter, but do not forget the mankind portion of the world and do good (as others) as He did good to mankind, and do not make trouble in this world. Allah loveth not those who do mischief.

Islam also teaches us to grab all the opportunities that exist for self-development, society, country and religion before it's too late or we will miss those opportunities. In the word of the Prophet Muhammad s.a.w., it is clear that the meaning reads: "Take advantage of the five conditions before the arrival of the other five - your youth before your old age, and your health before your illness, and your condition in the presence before your circumstances and your circumstances before your busy situation, still alive before your death". (Narrated by Al-Tirmizi)

Malaysia is striving to become a global Islamic financial services center capable of competing in international financial markets. We begin with the establishment of Bank Islam Berhad and we are moving towards a clear direction to be emulated by other countries, especially in terms of finance, banking and Islamic economics. As such, the field of Islamic tourism can also contribute to the national economy and boost the image of the country. Malaysia is now the focus of other Muslim countries and is an example for other countries. The new field of Islamic tourism also is being studied by other countries.

\section{Conclusion}

In Islamic tourism, compliance with religious observances is an important consideration. It should take into account aspects to promote a Sharia-compliant Islamic heritage tourism product attractive to observant Muslims. In Islamic tourism, the awareness of hotel entrepreneurs, travel agents and airlines agents about halal tourism is very important as it is one of the major issues in Islamic tourism applications. We need to re-evaluate the current situation of halal tourism to ensure it is Syariah-compliant and identify the prospect and challenges of halal tourism in Malaysia. In addition, we need to re-evaluate halal issues in the tourism sector. Halal tourism is a form of tourism for Muslims who want shariah-compliant services, activities and facilities. In addition, at the stage of idea and thought, Islamic tourism emphasizes Tauhid-compliant and Shariahcompliant aspects at the practice, ethics, and value levels. 


\section{References}

[1] Al-Attas, S. M. N. (1985). Is/am, Secularism and the Philosophy of the Future. London: Mansell Publishing Limited.

[2] Al-Maududi, A. A. (1989). Mabadi' al-Is/am. Riyadh: Al-Riasah al-'Ammah Li al-Idarat al-Buhuth al-Alamiyyah.

[3] Al-Mubarakpuri. S. R. (2000). Ar-Raheeq Al-Makhtum. (The Sealed Nectar). Memoirs of the Noble Prophet [pbuh]. Riyadh: Dar-rus-salam Publications.

[4] Abdullah, A. A. (2014). Is/am Yang Dinamik. Serdang: UPM Press.

[5] Badi, J. A. (2002). Sharh Arba'een an Nawawî (Commentary of Forty hadiths Of an Nawawi). Retrieved from http://fortyhadith.iiu.edu.my/.

[6] Battour, M. and Ismail, M. N. (2015). Halal tourism: Concepts, practises, challenges and future, Tourism Management Perspectives. Retrieved from http://dx.doi.org/10. 1016/j.tmp.2015.12.008.

[7] Carboni, M., Perelli, C. and Sistu, G. (2014). Is Islamic tourism a viable option for Tunisian tourism? Insights from Djerba. Tourism Management Perspectives, vol. 11, pp. $1-9$.

[8] Chapra, M. U. (2008). The Is/amic Vision of Development in the Light of Maqasid al-Shari'ah. Jeddah: Islamic Research and Training Institute.

[9] Duman, T. (2011). Value of Islamic Tourism Offering: Perspectives from the Turkish Experience, Paperwork. Presented at World Islamic Tourism Forum, Kuala Lumpur, Malaysia.

[10] Hamka. (1982). Studi Islam. Singapore: Pustaka Nasional Pte. Ltd.

[11] Kamali, H. (2007). Principles of Islamic Jurisprudence. Kuala Lumpur: IImiah Publishers. 